\title{
PENGEMBANGAN KEGIATAN BELAJAR ILMU PENGETAHUAN ALAM - KIMIA MELALUI METODE STRUKTURAL ANALITIK SINTETIK SEBAGAI UPAYA MENINGKATKAN AKTIVITAS DAN HASIL BELAJAR SISWA
}

\author{
Hotmaria Siagian \\ Sekolah Menengah Atas Negeri 1 Sibolga, Sumatera Utara \\ hotmariasiagian@yahoo.co.id
}

\begin{abstract}
Abstrak: Penelitian ini bertujuan: mengetahui penerapan strategi pembelajaran dengan Metode Belajar Struktural Analitik Sintetik (SAS) pada siswa, mengetahui ada tidaknya peningkatan penguasaan materi pada mata pelajaran IPA - Kimia pada siswa melalui penerapan strategi belajar dengan Metode Belajar SAS, dan mengetahui keaktifan siswa dalam pembelajaran mata pelajaran IPA - Kimia pada siswa melalui penerapan strategi pembelajaran dengan Metode Belajar SAS. Hasil penelitian menunjukkan: (1) Hasil belajar peserta didik dengan penerapan Metode Belajar SAS khususnya pada materi pokok IPA - Kimia dalam mata pelajaran IPA - Kimia yaitu dari nilai hasil belajar. Terdapat peningkatan signifikan pada hasil belajar siklus I menunjukkan adanya kemajuan walaupun belum memuaskan namun terlihat ada peningkatan dari siklus I. Pada siklus I rata-rata nilai belajar sudah tercapai, namun belum melebihi angka 70, karena ketuntasan pada siklus I baru mencapai 73,68\% dengan nilai rata-rata 70,86. Selanjutnya, pada siklus II ketuntasan belajar dan rata-rata nilai sudah tercapai, karena pada siklus II ini ketuntasan sudah mencapai 92,11\% dengan nilai rata-rata 85,46., (2) Respon peserta didik dalam proses pembelajaran menggunakan Metode Belajar SAS pada IPA - Kimia dari data angket diperoleh hasil rata-rata $85 \%$. Jadi, penerapan strategi pembelajaran dengan Metode Belajar SAS telah menghasilkan perubahan pada keaktifan siswa dalam kegiatan belajar mengajar IPA - Kimia.
\end{abstract}

Kata Kunci: metode struktural analitik sintetik, aktivitas dan hasil belajar, IPA-Kimia

\begin{abstract}
This study aims: to determine the application of learning strategies with the Synthetic Analytical Structural Learning Method (SAS) in students, to determine whether there is an increase in students' mastery of material in Science - Chemistry subjects through the application of learning strategies with the SAS Learning Method, and to determine student activeness learning science subjects - Chemistry in students through the application of learning strategies with the SAS Learning Method. The results showed: (1) The learning outcomes of students with the application of the SAS Learning Method, especially on the subject matter of Science - Chemistry in the subject of Science - Chemistry, namely the value of learning outcomes. There was a significant increase in learning outcomes in cycle I indicating progress was not satisfactory, but there was an increase in cycle I. In cycle I the average learning score had been achieved, but had not exceeded 70, because completeness in cycle I had only reached $73.68 \%$ with an average value of 70.86. Furthermore, in cycle II learning completeness and the average value has been achieved, because in this cycle II completeness has reached $92.11 \%$ with an average value of 85.46., (2) The response of students in the learning process using the SAS Learning Method on IPA - Chemistry from the questionnaire data obtained an average of $85 \%$. So, the application of learning strategies with the SAS Learning Method has resulted in changes in student activeness in teaching and learning science - Chemistry.
\end{abstract}

Keywords: synthetic analytical structural methods, learning activities and outcomes, Science-Chemistry

\section{PENDAHULUAN}

Mata pelajaran IPA di SMA bertujuan salah satunya agar siswa memiliki kemampuan mengembangkan pemahaman tentang berbagai macam gejala alam, konsep dan prinsip IPA yang bermanfaat dan dapat diterapkan dalam kehidupan sehari-hari sehingga terjadi peningkatan pengetahuan, konsep, dan keterampilan IPA sebagai dasar untuk melanjutkan pendidikan ke jenjang selanjutnya (BSNP, 2006: 155).

Untuk mencapai tujuan tersebut
diperlukan berbagai upaya melalui
inovasiinovasi strategi pembelajaran khususnya
oleh guru yang dapat memberikan pengalaman
langsung kepada siswa agar siswa memperoleh
pembelajaran melalui proses pembelajaran yang
memberikan pengalaman-pengalaman belajar
yang bermakna dan diselenggarakan secara
interaktif, aspiratif, menyenangkan, menantang,
memotivasi siswa untuk berpartisipasi aktif,
serta memberikan ruang yang cukup bagi


prakarsa, kreativitas, dan kemandirian sesuai bakat, minat, perkembangan fisik serta psikologis siswa. Karena "seorang siswa akan belajar lebih baik dan lebih bermakna apabila anak mengalami apa yang dipelajari dan bukan sekedar mengetahuinya (Depdiknas, 2002: 1).

Hal yang sering kita jumpai dalam pembelajaran di kelas yaitu, mengharapkan siswa belajar namun jarang mengajarkan mereka tentang proses belajar. Kita mengharapkan siswa untuk memecahkan masalah namun jarang mengajarkan mereka tentang pemecahan masalah. Dan sama halnya kita kadang-kadang meminta siswa mengingat sejumlah besar bahan ajar namun jarang mengajarkan bagaimana cara seni menghafal.

\section{Pengertian Hasil Belajar}

Hasil belajar adalah kemampuankemampuan yang dimiliki peserta didik setelah ia menerima pengalaman belajarnya. Yang menjadi tolok ukur bukan hanya nilai atau skor tetapi juga kematangan sikap dan juga kemampuan menguasai suatu ketrampilan. Dalam sistem pendidikan nasional rumusan tujuan pendidikan, baik tujuan kurikuler maupun tujuan instruksional, menggunakan klasifikasi hasil belajar dari Benyamin Bloom yang secara garis besar membaginya menjadi tiga ranah, yakni:

a. Ranah kognitif. Ranah kognitif merupakan ranah yang mencakup kegiatan mental (otak). Terdiri dari enam aspek, yakni:

1) Pengetahuan (knowledge) adalah kemampuan seseorang untuk mengingatingat kembali (recall) atau mengenali kembali tentang nama, istilah, ide, gejala, rumus-rumus dan sebagainya tanpa mengharapkan kemampuan untuk menggunakannya

2) Pemahaman (comprehension) adalah kemampuan seseorang untuk mengerti atau memahami sesuatu setelah sesuatu itu diketahui dan diingat.

3) Aplikasi adalah penggunaan abstraksi pada situasi kongret atau situasi khusus.

4) Analisis adalah usaha memilah suatu integritas menjadi unsurunsur atau bagian-bagian sehingga jelas hierarkinya dan atau susunannya.

5) Sintesis adalah penyatuan unsur-unsur atau bagian-bagian ke dalam bentuk menyeluruh.

6) Evaluasi adalah pemberian keputusan tentang nilai sesuatu yang mungkin dilihat dari segi tujuan, gagasan, cara kerja, pemecahan, metode, dan materil

b. Ranah afektif

Ranah afektif merupakan ranah yang berkaitan dengan sikap dan nilai. Terdiri dari lima aspek, yakni:

1) Reciving/attending, yakni semacam kepekaan dalam menerima rangsangan (stimulasi) dari luar yang datang kepada pesertadidik dalam bentuk masalah, situasi, gejala dan lain-lain.

2) Responding atau jawaban, yakni reaksi yang diberikan oleh seseorang terhadap stimulasi yang datang dari luar.

3) Valuing (penilaian) berkenaan dengan nilai dan kepercayaan terhadap gejala atau stimulus tadi.

4) Organisasi, yakni pengembangan dari nilai ke dalam satu sistem organisasi,termasuk hubungan satu nilai dengan nilai lain, pemantapan, dan prioritas nilai yang telah dimilikinya.

5) Karakteristik nilai atau internalisasi nilai, yakni keterpaduan semua sistem nilai yang telah dimiliki seseorang, yang mempengaruhi pola kepribadian dan tingkah lakunya.

c. Ranah Psikomotorik. Ranah psikomotorik merupakan ranah yang berkaitan dengan keterampilan (skill) atau kemampuan bertindak setelah seseorang menerima pengalaman belajar tertentu.

Terdiri dari enam tingkatan keterampilan yakni:

1) Gerakan refleks (keterampilan pada gerakan yang tidak sadar).

2) Keterampilan pada gerakan-gerakan dasar.

3) Kemampuan perseptual, termasuk di dalamnya membedakan visual, membedakan auditif, dan motoris.

4) Kemampuan di bidang fisik, misalnya kekuatan, keharmonisan, danketepatan.

5) Gerakan-gerakan skill, mulai dari keterampilan sederhana sampai pada keterampilan yang kompleks.

6) Kemampuan yang berkenaan dengan komunikasi nondekursive seperti gerakan ekspresif dan interpretative

\section{Metode Belajar Struktural Analitik Sintetik (SAS)}

Struktural Analitik Sintetik (SAS)

Menurut Supriyadi (1996) pengertian metode SAS adalah suatu pendekatan cerita 
yang disertai dengan gambar, yang didalamnya terkandung unsur struktur analitik sintetik. Metode SAS menurut Djauzak (1996) adalah suatu metode pembelajaran menulis permulaan yang didasarkan atas pendekatan cerita yakni cara memulai mengajar menulis dengan menampilkan cerita yang diambil dari dialog siswa dan guru atau siswa dengan siswa.

Metode ini diprogramkan pemerintah RI mulai tahun 1974. Regu yang dipimpin oleh Dr. A.S. Broto pada waktu itu telah menghasilkan Metode SAS. Menurut A.S. Broto khususnya disediakan untuk belajar membaca dan menulis permulaan di kelas permulaan SD. Lebih luas lagi Metode SAS dapat dipergunakan dalam berbagai bidang pengajaran.

Dalam proses operasionalnya metode SAS mempunyai langkah-langkah berlandaskan operasional dengan urutan: Struktural menampilkan keseluruhan; Analitik melakukan proses penguraian; Sintetik melakukan penggabungan kembali kepada bentuk Strukturalsemula. Landasan linguistiknya bahwa itu ucapan bukan tulisan, unsur bahasa dalam metode ini ialah kalimat; bahwa bahasa Indonesia mempunyai struktur tersendiri.

$$
\text { Landasan pedagogiknya; }
$$

mengembangkan potensi dan pengalaman anak, (2) membimbing anak menemukan jawab suatu masalah. Landasan psikologisnya: bahwa pengamatan pertama bersifat global (totalitas) dan bahwa anak usia sekolah memiliki sifat melit (ingin tahu).

Teknik pelaksanaan pembelajaran metode SAS yakni keterampilan menulis huruf, kartu suku kata, kartu kata dan kartu kalimat. Proses operasional metode SAS mempunyailangkah-angkah dengan urutan sebagai berikut:

a. Struktur yaitu menampilkan keseluruhan,

b. Analitik yaitu melakukan proses penguraian,

c. Sintetik yaitu melakukan penggabungan pada struktur semula.

Demikian langkah-langkah yang dapat dilakukan dalam pembelajaran menulis permulaan dengan metode SAS, sehingga hasil belajar itu benar-benar menghasilkanStruktur Analitik Statis. (Subana: 176).

Prosedur penggunaan Metode Belajar SAS antara lain sebagai berikut:

a. Mula membaca permulaan dijadikan dua bagian Bagian pertama Membaca permulaan tanpa buku Bagian pertama Membaca permulaan buku b. Merekam bahasa anak melalui pertanyaanpertanyaan dari pengajar sebagai kontak permulaan.

c. Menampilkan gambar sambil bercerita. Setiap kali gambar diperlihatkan, muncullah kalimat anak-anak yang sesuai dengan gambar.

d. Membaca kalimat secara structural

e. Membaca permulaan dengan buku

f. Membaca lanjutan

g. Membaca dalam hati

Metode Belajar SAS dapat diaplikasikan sebagai landasan berpikir analisis. Dengan langkah-langkah yang diatur sedemikian rupa membuat anak mudah mengikuti prosedur dan akan dapat cepat membaca pada kesempatan berikutnya. Berdasarkan landasan linguistik metode ini akan menolong anak menguasai bacaan dengan lancar.

Kegiatan pembelajaran menulis permulaan dengan metode SAS dilakukan dengan langkah-langkah sebagai berikut:

a. Guru bercerita atau berdialog dengan siswa.

b. Memperlihatkan gambar yang berhubungan dengan isi cerita.

c. Menulis beberapa kalimat sebagai kesimpulan dari isi cerita.

d. Menulis satu kalimat yang diambil dari isi cerita.

e. Menulis kata-kata sebagai uraian dari kalimat.

f. Menulis suku-suku kata sebagai uraian dari kata-kata.

g. Menuliskan huruf -huruf sebagai uraian dari suku-suku kata.

h. Mensintesiskan huruf-huruf menjadi sukusuku kata.

i. Menyatukan kata-kata menjadi kalimat.

\section{Teori yang mendasari Metode Belajar Struktural Analitik Sintetik (SAS)}

Strategi belajar merujuk kepada perilaku dan proses-proses pemikiran yang digunakan siswa yang mempengaruhi apa yang dipelajarinya, termasuk ingatan dan proses kognitif. Nama lain untuk strategi belajar adalah strategi kognitif. Contoh tujuankognitif tradisional yang diharapkan dicapai siswa adalah pemahaman suatu wacana dalam sebuah buku.

Pembelajaran dengan penerapan strategistrategi belajar berpedoman pada premis, bahwa keberhasilan siswa banyak bergantung kepada kemahiran mereka untuk belajar sendiri. Hal ini 
menyebabkan pentingnya metode-metode belajar diajarkan kepada anak didik dimulai dari sekolah dasar dan berlanjut pada pendidikan menengah dan tinggi. Dalam pembelajaran dengan penerapan strategi belajar Metode Belajar SAS.

Tujuan penelitian dan pengembangan ini adalah sebagai berikut: (1) mengetahui penerapan strategi pembelajaran dengan Metode Belajar SAS pada siswa; (2) mengetahui ada tidaknya peningkatan penguasaan materi pada mata pelajaran IPA Kimia pada siswa melalui penerapan strategi belajar dengan Metode Belajar SAS, dan (3) mengetahui keaktifan siswa dalam pembelajaran mata pelajaran IPA - Kimia pada siswa melalui penerapan strategi pembelajaran dengan Metode Belajar SAS.

Hipotesis adalah dugaan yang mungkin benar atau mungkin juga salah. Penulis dapat mengambil hipotesis tindakan sebagai berikut: Terdapat peningkatan hasil belajar IPA - Kimia peserta didik kelas XI Semester Genap di SMA Negeri 1 Sibolga tahun pelajaran 2016/2017 setelah diterapkan pembelajaran berdasarkan Metode Belajar Struktural Analitik Sintetik (SAS) pada materi pokok IPA - Kimia.

\section{METODE}

Penelitian ilmiah ini tidak akan dapat dilepaskan dari tahap-tahap yang saling berkaitan. Tahap-tahapan tersebut diantaranya proses penentuan masalah, pencarian data, hingga analisa data secara utuh dan tidak terpisah. Hilang atau tidak dilaksanakannya salah satu tahapan tersebut, maka akan dapat mengurangi atau bahkan menghilangkan bobot kelayakan hasil penelitian. Hal tersebut akan berlaku dalam penelitian yang peneliti laksanakan. Penelitian yang berbasis pada penelitian kelas atau juga dikenal dengan istilah PTK jaga memerlukan tahapan-tahapan seperti yang disebutkan di atas. Penelitian tindakan kelas merupakan penelitian yang bertujuan sebagai upaya untuk meningkatkan ketrampilan guru atau dosen dan hasil belajar siswa atau mahasiswa. Pengertian tersebut secara tersirat mengandung makna bahwa tujuan utama penelitian tindakan kelas adalah upaya perbaikan dan peningkatan layanan profesionalitas tindakan kelas dalam menangani proses belajar mengajar yang dicapai melalui mendiagnosa keadaan yang direfleksikan.

Penelitian ini dilaksanakan di kelas XI SMA Negeri 1 Sibolga, Kota Sibolga, Provinsi
Sumatera Utara dan pada saat proses belajar mengajar.

\section{Teknik Pengumpulan Data}

Dalam hal ini, digunakan beberapa metode untuk menggali informasi yang dibutuhkan. Metode yang dipakai untuk mendapatkan informasi tersebut antara lain sebagai berikut:

a. Metode Tes Metode tes merupakan serentetan pertanyaan atau latihan serta alat yang lain untuk mengatur keterampilan, pengetahuan, inteligensi, kemampuan atau bakat yang dimiliki oleh individu/ kelompok. Metode ini digunakan untuk mengetahui hasil belajar peserta didik.

b. Metode Angket Metode angket merupakan salah satu cara pengumpulan data yang dilakukan dengan cara memberi seperangkat pertanyaan-pertanyaan tertulis kepada responden untuk dijawab. Metode ini digunakan untuk mengetahui permasalahan yang dihadapi oleh peserta didik.

c. Metode Observasi Yaitu metode pengumpulan data melalui pengamatan dan pencatatan terhadap suatu gejala, proses kerja dan perilaku IPA - Kimia. Metode ini digunakan untuk mengetahui pelaksanaan pembelajaran IPA - Kimia materi pokok IPA - Kimia dengan menggunakan Metode Belajar SAS pada peserta didik kelas XI.

d. Metode Wawancara Wawancara dilakukan dengan siswa pada saat observasi awal dan setelah pelaksanaan penelitian. Aspek yang diungkap adalah penggunaan Metode Belajar SAS dalam pembelajaran IPA pada siswa kelas IV, solusi yang diambil oleh guru serta kendala yang dihadapi. Hasil wawancara dijadikan sebagai dasar pijakan dalam melakukan proses penelitian. Wawancara selanjutnya dilakukan setelah pelaksanaan penelitian. Hal ini untuk mengungkap keberhasilan penggunaan Metode Belajar SAS dalam pembelajaran IPA dapat meningkatkan hasil belajar siswa.

Desain penelitian tindakan kelas mengacu pada ketentuan pokok dalam pelaksanaan penelitian tindakan kelas. Ketentuan pokok tersebut tidak lain adalah penerapan empat langkah penting dalam pelaksanaan penelitian tindakan kelas. Keempat langkah tersebut meliputi perencanaan, tindakan, pengamatan dan refleksi yang menjadi satu kesatuan utuh dalam sebuah siklus pembelajaran. Penelitian tindakan kelas ini 
dirancang dalam empat tahap, yakni tahap pra siklus, siklus pertama, siklus kedua dan siklus ketiga.

\section{Teknik Analisis Data}

Analisis Kualitatif. Analisis kualitatif digunakan untuk mengetahui perubahan hasil belajar semua siswa pada mata pelajaran. IPA Kimia pada materi IPA - Kimia, data yang terkumpul dari responden dianalisis secara deskriptif dengan melihat gejala atau tandatanda dapat yang dilihat dari kesiapan dalam menerima pelajaran, suasana kelas pada saat akan dimulainya pelajaran, ketaatan terhadap peraturan kelas dan keaktifan dalam kerja kelompok. Hasil pengamatan dan tes diolah dengan analisis deskriptif untuk menggambarkan keadaan peningkatan pencapaian indikator keberhasilan pembelajaran dengan menggunakan Metode Belajar SAS dalam pembelajaran yang dapat meningkatkan hasil belajar peserta didik. Pada umumnya, penelitian dengan analisis deskriptif merupakan penelitian non hipotesis. Oleh sebab itu, dalam penelitian ini juga tidak perlu dirumuskan hipotesis.

\section{HASIL DAN PEMBAHASAN Siklus I}

Selama proses pembelajaran siklus I berlangsung dengan menggunakan Metode Belajar SAS, peserta didik melakukan kegiatankegiatan yang dirancang sesuai dengan silabus dan RPP. Kegiatan-kegiatan yang dilakukan antara lain peneliti memberi penjelasan tentang materi yang akan disampaikan dan tugas-tugas yang harus dilakukan peserta didik dan kelompoknya. Peneliti menjelaskan langkahlangkah pembelajaran. Di akhir pembelajaran peserta didik dibimbing untuk menarik kesimpulan kemudian peneliti memberikan test evaluasi untuk mengetahui penguasaan peserta didik terhadap materi yang telah dipelajari.

Dari pengamatan siklus I diperoleh data hasil pengamatan antara lain peneliti dalam melaksanakan pembelajaran dengan Metode Belajar SAS kurang optimal. Hal ini disebabkan peneliti kurang memberi motivasi dan bimbingan terhadap peserta didik baik dalam kelompok maupun individu kurang merata sehingga peserta didik menjadi pasif dan kurang memahami materi yang telah disampaikan dan kurang paham tentang jalannya proses pembelajaran Metode Belajar SAS.
Berdasarkan hasil refleksi pada siklus I, dihasilkan antara lain sebagian besar peserta didik dalam melaksanakan pembelajaran dengan Metode Belajar SAS belum mampu menerapkannya selanjutnya dengan diskusi kelompok masih belum terbiasa. Hal ini nampak dari peserta didik yang tidak dapat langsung mengkondisikan diri dalam bentuk kelompok sehingga terjadi keributan. Dalam mengerjakan LKS, interaksi peserta didik dalam kelompoknya seperti saling bertanya, saling menanggapi pendapat, saling menjelaskan, dan saling bekerja sama dalam kelompoknya nampak kurang dan lebih banyak didominasi oleh peserta didik yang pandai, sehingga peserta didik yang lain bersikap pasif, kurang berpartisipasi dan lebih banyak sebagai penonton. Dalam penyajian hasil kerja kelompok ketergantungan pada peserta didik yang pandaipun masih tinggi. Dari hasil evaluasi yang diperoleh ternyata masih belum mencapai indikator keberhasilan yang ditetapkan. Dengan demikian, siklus II perlu dilakukan agar aktivitas dan hasil belajar peserta didik dalam kegiatan pembelajaran dapat meningkat.

\section{Siklus II}

Untuk pelaksanaan pembelajaran siklus II, peneliti mempersiapkan silabus dan RPP secara keseluruhan disusun tidak berbeda dari siklus sebelumnya, tetapi dalam pelaksanaannya lebih diatur dalam setiap kegiatan. Dari data pengamatan yang diperoleh pada siklus II, pelaksanaantindakan guru sudah baik. Peneliti memberi motivasi belajar dan membimbing peserta didik sudah merata baik secara individu maupun kelompok. Sehingga peserta didik menjadi lebih semangat dan antusias dalam proses pembelajaran. Disamping itu, peserta didik juga menjadi aktif dan mudah memahami materi yang telah disampaikan.

Pada pengamatan siklus II, peserta didik sudah mulai terbiasa dengan adanya diskusi kelompok seperti saling bertanya, saling menanggapi pendapat, saling menjelaskan, dan saling bekerja sama. Serta ketergantungan terhadap peserta didik yang pandai semakin berkurang dan sudah bisa menkondisikan diri dalam kelompok masingmasing.

Dari data pengamatan siklus II hasil belajar yang dicapai dengan nilai rata-rata yang sudah memenuhi nilai minimal kelas dan ketuntasan $90 \%$ dari perserta didik. Dari data tersebut ternyata hasil belajar peserta didik 
sudah cukup mencapai indikator keberhasilan yang ditentukan. Sehingga siklus II dipandang sudah cukup karena dengan menggunakan Metode Belajar SAS dapat meningkatkan hasil belajar peserta didik.

\section{Peningkatan Hasil Belajar Melalui Penerapan Metode Belajar Struktural Analitik Sintetik (SAS)}

Hasil observasi penelitian mengenai peningkatan penguasaan materi belajar pada pembelajaran IPA - Kimia melalui penerapan strategi belajar dengan Metode Belajar SAS pada siswa kelas XI ini dilakukan dengan menilai hasil tes/evaluasi pada setiap akhir kegiatan pembelajaran. Adapun hasil tes/evaluasi siswa dalam setiap siklus yaitu sebagai berikut:

\section{Analisis Deskriptif Hasil Tes Akhir Pada Siklus I}

Setelah selesai kegiatan dengan beberapa kali pertemuan maka dilaksanakan tes/evaluasi akhir untuk mengetahui hasil belajar siswa setelah dilakukan tindakan pada siklus I. Sebagai hasil analisis deskriptif nilai perolehan hasil belajar materi IPA - Kimiapada mata pelajaran IPA - Kimia siswa dapat dilihat pada Tabel 1.

Tabel 1. Statistik Nilai Hasil Belajar Pada Siklus I

\begin{tabular}{|l|l|c|}
\hline No & \multicolumn{1}{|c|}{ Statistik } & $\begin{array}{c}\text { Angka } \\
\text { Statistik }\end{array}$ \\
\hline 1 & Jumlah Siswa & 38 \\
\hline 2 & Kriteria Ketuntasan Minimal & 70 \\
\hline 3 & Tuntas & 28 \\
\hline 4 & Belum Tuntas & 10 \\
\hline 5 & Nilai Tertinggi & 90 \\
\hline 6 & Nilai Terendah & 55 \\
\hline 7 & Rentang Nilai (Jangkauan) & 35 \\
\hline 8 & Rata-Rata (Mean) & 70,86 \\
\hline 9 & Simpangan Baku & 9,426 \\
\hline
\end{tabular}

Bila nilai penguasaan siswa seperti yang ditunjukkan pada Tabel 1 kemudian selanjutnya dikelompokkan ke dalam beberapa kategori tingkatan, maka distribusi frekuensi dan presentase nilai penguasaan siswa hasil belajar pada mata pelajaran IPA - Kimia dapat diperlihatkan pada Tabel 2 berikut.
Tabel 2. Distribusi Frekuensi dan Presentase Penguasaan Siklus I

\begin{tabular}{|c|l|c|c|}
\hline $\begin{array}{c}\text { Rentang } \\
\text { Nilai }\end{array}$ & Kategori & $\begin{array}{c}\text { Frekuensi } \\
(\text { Orang })\end{array}$ & $\begin{array}{c}\text { Presentase } \\
(\%)\end{array}$ \\
\hline $0-35$ & $\begin{array}{l}\text { Sangat } \\
\text { Rendah }\end{array}$ & 0 & 0 \\
\hline $36-69$ & Rendah & 10 & 26,32 \\
\hline & $\begin{array}{l}\text { Tidak } \\
\text { Tuntas }\end{array}$ & 10 & 26,32 \\
\hline $70-79$ & Sedang & 14 & 46,84 \\
\hline $80-89$ & Tinggi & 12 & 31,58 \\
\hline $90-100$ & $\begin{array}{l}\text { Sangat } \\
\text { Tinggi }\end{array}$ & 2 & 5,26 \\
\hline & Tuntas & 28 & 73,68 \\
\hline & TOTAL & 38 & 100 \\
\hline
\end{tabular}

\section{Analisis Deksriptif Hasil Tes Akhir Pada Siklus II}

Analisis deskriptif dari penguasaan materi dalam bentuk nilai hasil belajar siswa, seperti yang disajikan pada Tabel 3 .

Tabel 3. Statistik Nilai Hasil Belajar Pada Siklus II

\begin{tabular}{|l|l|c|}
\hline No & \multicolumn{1}{|c|}{ Statistik } & $\begin{array}{c}\text { Angka } \\
\text { Statistik }\end{array}$ \\
\hline 1 & Jumlah Siswa & 38 \\
\hline 2 & Kriteria Ketuntasan Minimal & 70 \\
\hline 3 & Tuntas & 35 \\
\hline 4 & Belum Tuntas & 3 \\
\hline 5 & Nilai Tertinggi & 95 \\
\hline 6 & Nilai Terendah & 65 \\
\hline 7 & Rentang Nilai (Jangkauan) & 30 \\
\hline 8 & Rata-Rata (Mean) & 85,46 \\
\hline 9 & Simpangan Baku & 7,482 \\
\hline
\end{tabular}

Dari hasil belajar siswa seperti yang ditunjukkan pada Tabel 4.4 dapat dikelompokkan menjadi kategorisasi sebagai distribusi frekuensi dan presentasi nilai hasil belajar siswa pada siklus II, seperti yang ditunjukkan pada Tabel 4. berikut.

Tabel 4. Distribusi Frekuensi dan Presentase Penguasaan Siklus II

\begin{tabular}{|c|l|c|c|}
\hline $\begin{array}{c}\text { Rentang } \\
\text { Nilai }\end{array}$ & Kategori & $\begin{array}{c}\text { Frekuensi } \\
(\text { Orang) }\end{array}$ & $\begin{array}{c}\text { Presentase } \\
(\%)\end{array}$ \\
\hline $0-35$ & $\begin{array}{l}\text { Sangat } \\
\text { Rendah }\end{array}$ & 0 & 0 \\
\hline $36-69$ & Rendah & 3 & 7,89 \\
\hline & $\begin{array}{l}\text { Tidak } \\
\text { Tuntas }\end{array}$ & 3 & 7,89 \\
\hline $70-79$ & Sedang & 7 & 18,42 \\
\hline $80-89$ & Tinggi & 20 & 52,63 \\
\hline
\end{tabular}




\begin{tabular}{|c|l|c|c|}
\hline $\begin{array}{c}\text { Rentang } \\
\text { Nilai }\end{array}$ & Kategori & $\begin{array}{c}\text { Frekuensi } \\
(\text { Orang })\end{array}$ & $\begin{array}{c}\text { Presentase } \\
(\%)\end{array}$ \\
\hline $90-100$ & $\begin{array}{l}\text { Sangat } \\
\text { Tinggi }\end{array}$ & 8 & 21,05 \\
\hline & Tuntas & 35 & 92,11 \\
\hline & TOTAL & 38 & 100 \\
\hline
\end{tabular}

Kemudian dilakukan pengelompokkan terhadap tingkat ketuntasan belajar siswa dari tes awal, tes akhir siklus I, sampai pada tes akhir siklus II dapat dilihat pada Tabel 5.

Tabel 5. Tingkat Ketuntasan Belajar Siswa

\begin{tabular}{|c|c|c|c|c|c|}
\hline $\begin{array}{l}\mathrm{N} \\
\mathrm{O}\end{array}$ & $\begin{array}{c}\text { Kegiat } \\
\text { an }\end{array}$ & $\begin{array}{c}\text { Juml } \\
\text { ah } \\
\text { Tunt } \\
\text { as }\end{array}$ & $\begin{array}{l}\text { Present } \\
\text { ase (\%) }\end{array}$ & $\begin{array}{c}\text { Jumla } \\
\text { h } \\
\text { Tidak } \\
\text { Tunta } \\
\text { s } \\
\end{array}$ & $\begin{array}{c}\text { Prese } \\
\text { ntase } \\
(\%)\end{array}$ \\
\hline 1 & \begin{tabular}{|l|} 
TES \\
SIKL \\
US I
\end{tabular} & 28 & 73,68 & 10 & $\begin{array}{c}26,3 \\
2\end{array}$ \\
\hline 2 & $\begin{array}{l}\text { TES } \\
\text { SIKL } \\
\text { US II } \\
\end{array}$ & 35 & 92,11 & 3 & 7,89 \\
\hline
\end{tabular}

Dari Tabel 5 menunjukkan tingkat ketuntasan belajar siswa yang terjadi peningkatan. Dimana hal ini menunjukkan prestasi belajar siswa setelah dilakukan tindakan kelas baik pada siklus I maupun siklus II terjadi peningkatan yang sangat signifikan.

Secara umum dapat disimpulkan bahwa hasil belajar siswa setelah dilakukan tindakan kelas khususnya penerapan pembelajaran dengan Metode Belajar SAS dalam materi pelajaran IPA di kelas XI telah terjadi peningkatan yang sangat signifikan.

Tingkat prestasi belajar siswa setelah melaluai beberapa tahap kegiatan pada tes awal, tes akhir siklus I, dan tes akhir siklus II dapat dilihat pada Tabel 6 berikut.

Tabel 6. Tingkat Prestasi Hasil Belajar Siswa

\begin{tabular}{|l|l|c|c|}
\hline No & \multicolumn{1}{|c|}{ Statistik } & $\begin{array}{c}\text { Tes } \\
\text { Akhir } \\
\text { Siklus I }\end{array}$ & $\begin{array}{c}\text { Tes Akhir } \\
\text { Siklus II }\end{array}$ \\
\hline 1 & Nilai Rata-Rata & 70,86 & 85,46 \\
\hline 2 & Nilai Tertinggi & 90 & 95 \\
\hline 3 & Nilai Terendah & 55 & 65 \\
\hline
\end{tabular}

Berdasarkan keseluruhan pembahasan di atas maka dapat diambil suatu kesimpulan terhadap hipotesis yang diajukan, yaitu "Adanya kenaikan penguasaan materi IPA Kimiadalam pembelajaran IPA - Kimia setelah diberikan tindakan kelas dengan Metode Belajar Struktural Analitik Sintetik (SAS)" dapat diterima sebagai suatu kebenaran.

Pada pra siklus atau kegiatan awal sebelum siklus I dilakukan, guru menjelaskan materi pada siswa dengan menggunakan metode mengajar ceramah bervariasi. Berdasarkan hasil penelitian tindakan pra siklus diketahui hasil belajar siswa belum memuaskan. Ketuntasan belajar klasikal baru mencapai $55,26 \%$ dengan nilai rata-rata 62,34 .

Terdapat peningkatan signifikan pada hasil belajar siklus I menunjukkan adanya kemajuan walaupun belum memuaskan namun terlihat ada peningkatan dari siklus I. Pada siklus I rata-rata nilai belajar sudah tercapai, namun belum melebihi angka 70, karena ketuntasan pada siklus I baru mencapai 73,68\% dengan nilai rata-rata 70,86

Pada siklus II ketuntasan belajar dan ratarata nilai sudah tercapai, karena pada siklus II ini ketuntasan sudah mencapai 92,11\% dengan nilai rata-rata 85,46. Maka pembelajaran IPA Kimia menggunakan strategi belajar Metode Belajar Struktural Analitik Sintetik (SAS) berpengaruh terhadap penguasaan materi belajar terhadap siswa, hal ini dapat terlihat dengan adanya peningkatan pada ketuntasan belajar perorangan dan ketuntasan belajar.

\section{Peningkatan Keaktifan Siswa Melalui Penerapan Metode Belajar Struktural Analitik Sintetik (SAS)}

Hasil observasi penelitian mengenai peningkatan keaktifan siswa pada materi belajar mata pelajaran IPA - Kimia melalui penerapan strategi pembelajaran dengan Metode Belajar SAS pada siswa kelas XI SMA Negeri 1 Sibolga ahun pelajaran 2016/2017 ini dilakukan dengan menilai keaktifan siswa dalam kegiatan pembelajaran antara lain lain seperti mengajukan dan menjawab pertanyaan, berpendapat, membuat laporan ataupun kegiatan presentasi siswa.

Hasil penilaian guru terhadap keaktifan siswa pada pembelajaran IPA - Kimia pada siklus I dan siklus II dapat dilihat pada Tabel 7 berikut:

Tabel 7. Nilai Keaktifan Peserta Didik

\begin{tabular}{|l|l|c|c|}
\hline No & \multicolumn{1}{|c|}{$\begin{array}{c}\text { Keaktifan Peserta } \\
\text { Didik }\end{array}$} & $\begin{array}{c}\text { Siklus } \\
\text { I (\%) }\end{array}$ & $\begin{array}{c}\text { Siklus } \\
\text { II (\%) }\end{array}$ \\
\hline 1 & $\begin{array}{l}\text { Mengajukan } \\
\text { Pertanyaan }\end{array}$ & 35,00 & 65,00 \\
\hline 2 & Menjawab & 40,00 & 70,00 \\
\hline
\end{tabular}




\begin{tabular}{|l|l|c|c|}
\hline No & \multicolumn{1}{|c|}{$\begin{array}{c}\text { Keaktifan Peserta } \\
\text { Didik }\end{array}$} & $\begin{array}{c}\text { Siklus } \\
\text { I }(\%)\end{array}$ & $\begin{array}{c}\text { Siklus } \\
\text { II (\%) }\end{array}$ \\
\hline & Pertanyaan & & \\
\hline 3 & $\begin{array}{l}\text { Mengemukakan } \\
\text { Pendapat }\end{array}$ & 40,00 & 65,00 \\
\hline 4 & Membuat Laporan & 65,00 & 85,00 \\
\hline 5 & $\begin{array}{l}\text { Mempresentasikan } \\
\text { Hasil Kegiatan }\end{array}$ & 60,00 & 95,00 \\
\hline & Rata-rata & 48,00 & 76,00 \\
\hline
\end{tabular}

Jadi dapat dibuat suatu kesimpulan, bahwa dengan penerapan strategi pembelajaran dengan Metode Belajar SAS telah menghasilkan perubahan pada keaktifan siswa dalam kegiatan belajar mengajar IPA - Kimia. Dimana siswa menjadi lebih aktif dalam bertanya maupun menjawab suatu pertanyaan yang diberikan guru, siswa lebih aktif untuk berpendapat, siswa lebih giat dalam pembuatan laporan atau ringkasan, dan yang paling penting siswa lebih percaya diri dalam kegiatan presentasi dengan teman-teman di kelas.

\section{PENUTUP}

Berdasarkan hasil penelitian yang penulis lakukan tentang penerapan Metode Belajar SAS (preview, Question, Read, Recite, Reflect and Review) sebagai salah satu upaya dalam meningkatkan hasil belajar pada materi pokok IPA - Kimia, dapat diambilkesimpulan bahwa:

a. Hasil belajar peserta didik dengan penerapan Metode Belajar SAS khususnya pada materi pokok IPA - Kimia dalam mata pelajaran IPA - Kimia yaitu dari nilai hasil belajar. Terdapat peningkatan signifikan pada hasil belajar siklus I menunjukkan adanya kemajuan walaupun belum memuaskan namun terlihat ada peningkatan dari siklus I. Pada siklus I rata-rata nilai belajar sudah tercapai, namun belum melebihi angka 70 , karena ketuntasan pada siklus I baru mencapai $73,68 \%$ dengan nilai rata-rata 70,86. Selanjutnya, pada siklus II ketuntasan belajar dan rata-rata nilai sudah tercapai, karena pada siklus II ini ketuntasan sudah mencapai $92,11 \%$ dengan nilai rata-rata 85,46. Maka pembelajaran IPA - Kimia menggunakan strategi belajar Metode Belajar SAS berpengaruh terhadap penguasaan materi belajar terhadap siswa, hal ini dapat terlihat dengan adanya peningkatan pada ketuntasan belajar perorangan dan ketuntasan belajar. b. Respon peserta didik dalam proses pembelajaran menggunakan Metode Belajar SAS pada IPA - Kimia dari data angket diperoleh hasil rata-rata $85 \%$. Jadi, penerapan strategi pembelajaran dengan Metode Belajar SAS telah menghasilkan perubahan pada keaktifan siswa dalam kegiatan belajar mengajar IPA - Kimia. Dimana siswa menjadi lebih aktif dalam bertanya maupun menjawab suatu pertanyaan yang diberikan guru, siswa lebih aktif untuk berpendapat, siswa lebih giat dalam pembuatan laporan atau ringkasan, dan yang paling penting siswa lebih percaya diri dalam kegiatan presentasi dengan teman-teman di kelas.

\section{DAFTAR PUSTAKA}

Almatsier, Sunita, Prinsip Dasar Ilmu Gizi, Jakarta: PT Gramedia Pustaka Utama, 2006.

Arikunto, Suharsimi, Penelitian Tindakan Kelas, Jakarta: Bumi Aksara, 2008

Arikunto, Suharsimi, Prosedur Penelitian Suatu Pendekatan Praktek, Jakata: Rineka Cipta, 2002

Baharudin dan Esa Nur Wahyuni, Teori Belajar Dan Pembelajaran, Yogyakarta: ArRuzz, 2007

Hadi, Amirul dan Haryano, Metodologi Penelitian Pendidikan, Bandung: Pustaka Setia, 1998.

Hadjar, Ibnu, Dasar-dasar Metodologi Kuantitatif dalam Pendidikan, Jakarta: Raja Grafindo Persada,1996

Margono, S., Metodologi penelitian Pendidikan, Jakarta: Rineka Cipta, 2000

Poerdarwinta, Kamus Umum Bahasa Indonesia, Jakarta: Balai Pustaka, 2003.

Mulyasa, E., Kurikulum Tingkat Satuan Pendidikan, Bandung: Rosdakarya, 2000,

Oemar Hamalik, Psikologi Belajar dan Mengajar, Bandung: Sinar Baru Algensindo, 2004.

Poerwadarwinta, Wjs., Kamus Umum Bahasa Indonesia Edisi 3 Jakarta: Balai Pustaka, 2006.

Purwanto, M. Ngalim, Prinsip-Prinsip Dan Teknik Evaluasi Pengajaran, Bandung: Remaja Rosda Karya, 1998.

Sitorus, MH., Istilah-istilah Biologi, Bandung: Irama Widjaya, 1999.

Slameto, Belajar Dan Fakto-Faktor Yang Mempengarihinya, Jakarta: Rineka Cipta, 1995. 
Jurnal TIK dalam Pendidikan, Vol. 7 No. 1 Juni 2020, p-ISSN: 2355-4983, e-ISSN: 2407-7488

Subagyo, Joko, Metode Penelitian dalam Teori dan Praktek, Jakarta: Rineka Cipta, 1991.

Sudjana, Nana, Dasar-Dasar Proses Belajar Mengajar, Bandung: Sinar Baru Algesindo, 2005.
Sugiyono, Metode Penelitian Pendidikan (Pendidikan Kualitatif, Kuantitatif dan R \& D), Bandung: Alfabeta, 2007.

Trianto, Metode-Metode Pembelajaran Inovatif Berorientasi Konstruktifitas, Jakarta: Prestasi Pustaka, 2007. 